\title{
Ankilozan Spondilit Ön Tanılı Hastalarda HLA-B27 Sıklığı
}

\section{Frequency of HLA-B27 in Patients with Pre-Diagnosis of Ankylosing Spondylitis}

\author{
Kuyaş HEKIMLER ÖZTÜRK ${ }^{1 * \mathbb{D}}$, Halil ÖZBAŞ ${ }^{1}$ (D) , Muhammet Yusuf TEPEBAŞı ${ }^{1}$ (D), \\ Pınar ASLAN KOŞAR ${ }^{2}$ (D)
}

${ }^{1}$ Süleyman Demirel Üniversitesi, Tıp Fakültesi, Tıbbi Genetik AD, Isparta, Türkiye

${ }^{2}$ Süleyman Demirel Üniversitesi, Tıp Fakültesi, Tıbbi Biyoloji AD, Isparta, Türkiye

\begin{abstract}
Ö Z E T
Amaç: Ankilozan spondilitin (AS) oluşumunda genetik faktörlerin önemli olduğu kabul edilmiştir. Hastalığın patogenezinde rol alan en önemli genetik faktörlerden birinin insan lökosit antijen (HLA)-B27 olduğu bilinmektedir. Bu çalışmada AS ön tanılı hastalarda $H L A-B 27$ sıklığının tespit edilmesi ve hastaların demografik ve laboratuvar bulguları ile HLA-B27 arasındaki ilişkinin karşılaştırılması amaçlandı.
\end{abstract}

Materyal-Metod: AS ön tanılı 64'ü erkek, 91'i kadın olmak üzere toplam 155 hasta çalışmaya dahil edildi. Hastaların poliklinik takip dosyaları geriye dönük taranarak demografik özellikleri, genetik soyağacı bilgileri, laboratuvar bulguları ve HLA-B27 gen analizi sonuçları kaydedildi. Hastaların HLA-B27 analizleri Real-Time PCR yöntemi ile yapıldı.

Bulgular: Elde edilen bulgulara göre çalışmaya alınan AS ön tanılı hastaların 31'inde (\%20) HLA-B27 nin pozitif olduğu saptandı. Erkeklerde HLA-B27 pozitifliği daha yüksekti $(p=0,010)$. Yaş ortalaması cinsiyetler arasında fark göstermedi $(p>0,05)$. HLA-B27 pozitif olanların yaş ortalaması negatif olanlara kıyasla anlamlı derecede düşüktü $(p=0,047)$. Serum CRP ve sedimentasyon seviyeleri $H L A-B 27$ pozitifliğinde belirleyici değildi $(p>0,05)$. $H L A-B 27$ pozitif olan hastalarda aile öyküsü olanlar olmayanlara kıyasla daha fazlaydı $(\mathrm{p}=0,000)$.

Sonuç: AS semptomlarını taşıyan hastalarda HLA-B27 pozitiflik oranı literatürden farklı olarak düşük bulundu. $\mathrm{Bu}$ farklılığın, AS ön tanılı hastaların çalışmaya dahil edilmesi, farklı hasta popülasyonu, klinik varyasyonlar, farklı etnik köken ve farklı genetik ve/veya çevresel faktörlerden kaynaklanmış olabileceğini düşünmekteyiz. Toplumumuzda AS hastalarında HLA-B27 frekansını daha net ortaya koyabilmek için kesin tanı almış daha geniş hasta popülasyonunda çalışmalara ihtiyaç vardır. 


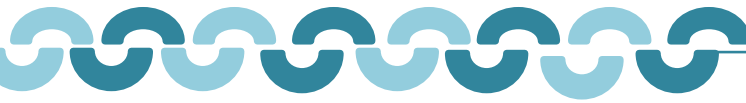

\author{
A B S T R A C T
}

Objectives: Genetic factors have been acknowledged as crucial in ankylosing spondylitis (AS) genesis. Human leukocyte antigen (HLA)-B27 known to play a role in the pathogenesis of the disease. In this study, it was aimed to determine the frequency of $H L A-B 27$ in patients with pre-diagnosis of AS and to compare the relationship between demographic and laboratory findings and HLA-B27.

Material-Method: A total of 155 patients, 64 male and 91 female, with pre-diagnosis of AS were included in the study. Demographic characteristics, pedigree information, laboratory findings and $H L A-B 27$ gene analysis results were recorded from the policlinic files of the patients. HLA-B27 analyzes were performed by Real-Time PCR method.

Results: HLA-B27 positivity was detected in $31(20 \%)$ of AS patients. HLA-B27 positivity was higher in men $(p=0.010)$. The mean age did not differ between the genders $(p>0.05)$. The mean age of those who were $H L A-$ $B 27$ positive was significantly lower than those who were negative $(\mathrm{p}=0.047)$. Serum CRP and sedimentation levels were not determinative in $H L A-B 27$ positivity $(p>0.05)$. It was more common in $H L A-B 27$ positive patients than those without family history $(p=0.000)$.

Conclusion: The $H L A-B 27$ positivity rate was found to be low in patients with AS symptoms. We suggest that this difference may be due to the inclusion of patients with pre-diagnosis of AS, different patient population, clinical variations, different ethnic origin and different genetic and/or environmental factors. In order to more clearly reveal the $H L A-B 27$ frequency in AS patients, studies with a larger patient population are needed.

\section{Giriş}

Ankilozan spondilit (AS), seronegatif spondiloartropatiler (SpA) adı verilen bir grup artropatinin prototipik hastalığıdır [1]. Özellikle sakroiliak eklemleri ve aksiyel iskeleti tutan kronik, ilerleyici inflamatuar romatizmal bir hastalıktır [2]. Hastalığın endikasyonları ve prevalansı, yaş, cinsiyet ve ırka göre farklııık göstermektedir [3]. AS'in patogenezi ve katkıda bulunan etiyolojik faktörler net olarak açıklığa kavuşturulamamıştır. Ancak, hastalığın patogenezinde genetik, çevresel ve immünolojik faktörlerin rol oynadığı bilinmektedir [4]. Genom çaplı ilişkilendirme çalışmalarıyla, majör doku uygunluk kompleksi $(\mathrm{MHC})$ lokusunun dışında kalan yatkınlık genleri belirlenmiş ve sonrasında da bu genlerin rolleri ortaya konulmuştur. Bununla birlikte, insan lökosit antijeni (HLA)-B27nnin AS'in patogenezinde önemli rol oynadığı ve AS kalıtsallığının $\% 20.1$ 'ine katkıda bulunduğu öne sürülmüştür [5]. Yapılan çalışmalarda, AS ile MHC üyesi olan $H L A-B 27$ arasında güçlü bir ilişki bulunmuştur ve farklı popülasyonlarda farklı dağılımlar raporlanmıştır [6]. HLA-B27 pozitifliği genel popülasyonun $\% 5$ 'inde görülürken, $H L A-B 27$ pozitif kişilerin sadece $\% 1-5$ 'inde AS görülmektedir [7]. Yapılan çalışmalarda Türk popülasyonunda AS hastalarının \%70'inde HLA-B27 pozitifliği saptanmıştır. Sağlıklı Türk popülasyonununda $H L A-B 27$ fenotip sıklığı ise $\% 6,8$ olarak bildirilmiştir [8].

AS'de hastalığın başlangıç yaşının genellikle 20-40 yaş aralığında olduğu ve erkeklerde görülme sıklığının kadınlara kıyasla daha yüksek olduğu gösterilmiştir. Bu oran erkeklerde \%0,54 iken kadınlarda \%0,44 olarak bildirilmiştir [6]. Ankilozan spondilitli hastalarla yapılan aile ve ikiz çalışmalarında, akrabalarında AS olan vakaların, genel popülasyondaki $H L A-B 27$ pozitif olan bireylere göre hastalığa yakalanma riskinin 5-16 kat arttığı bildirilmiştir [8]. Bununla birlikte, ailedeki akrabalık derecesi ne kadar yakınsa hastalık riskinin o kadar arttığı gösterilmiştir $[6,8]$ 
Bu çalışmada AS ön tanılı hastalarda $H L A-B 27$ frekansını ortaya koymak ve $H L A-B 27$ pozitifliğinin demografik özellikler ve laboratuvar bulgularıyla ilişkisini araştırmak amaçlanmıştır.

\section{Materyal ve Metot}

\section{Çalışma Grubu}

Araştırma protokolü Helsinki Bildirgesi'ne uygun olarak oluşturulmuş bu çalışma, Süleyman Demirel Üniversitesi Tıp Fakültesi Etik Kurulu tarafından onaylanmıştır (10.06.2021 tarihli ve 224 karar numaralı). Çalışmamıza, Süleyman Demirel Üniversitesi Hastanesi Tıbbi Genetik polikliniğine Ocak 2017 ile Haziran 2021 tarihleri arasında, ankilozan spodilit hastalığının semptom ve bulgularını taşıyan ve HLA-B27 test istemi ile tıbbi genetik polikliniğine başvuran 91'i kadın, 64'ü erkek olmak üzere toplam 155 hasta dahil edilmiştir. Tüm hastalardan yazılı bilgilendirilmiş onam alınmıştır. Hastaların poliklinik takip dosyaları taranarak, demografik özellikleri, genetik soyağacı bilgileri, laboratuvar bulguları ve HLA-B27 test sonuçları kaydedildi. Bu verilere göre; HLA-B27+ ve HLA-B27- AS hastalarında yaş, cinsiyet, aile öyküsü, sedimentasyon, CRP sonuçları karşılaştırıldı. Hastaların anamnez bilgilerinde eşlik eden hastalık öyküsü bilgisine ulaşılamadı.

\section{DNA İzolasyonu ve HLA-B27 Analizi}

Hastalardan EDTA'lı tüplere $2 \mathrm{ml}$ venöz kan alınarak spin kolon yöntemiyle (High pure PCR template preparation, Roche Diagnostic, USA) üretici talimatına uygun olarak DNA izolasyonu yapıldı. Elde edilen DNA örnekleri $1,5 \mathrm{ml}$ santrifüj tüplerine alınarak çalışma yapılana kadar $-20^{\circ} \mathrm{C}$ buzdolabında saklandı. HLA-B27 testi için geneMAPTM HLA-B27 kiti (GenMark Sağlık Ürünleri, Türkiye) kullanıldı. Kullanılan kit, $H L A-B 27$ nin en sık görülen alt tipleri dahil olmak üzere toplam 259 B-27 alt tipini kapsamaktadır.

Çalışmaya başlamadan önce, $-20^{\circ} \mathrm{C}$ 'den alınan DNA örnekleri çözdürüldü ve kısa spin atıldı. PCR bileşenleri olarak, 2X HLA-B27 master miks, 10X primer miks (Hedef ve endojen kontrol primerleri) ve $\mathrm{ddH}_{2} \mathrm{O}$ kullanıldı. Hazırlanan PCR miksi kuyucuklara eşit olarak dağıtıldı. Daha sonra pozitif kontrol (sentetik DNA) ve hasta DNA'ları $3 \mu \mathrm{l}$ kadar eklendi. PCR tüplerinin kapağı kapatılarak RT-PCR cihazına yerleştirildi. Koşum öncesi ön ayarlarda, flofor olarak FAM, EvaGreen ve SyberGreen; hedef olarak HLA-B27 aleli ve endojen kontrol seçildi. Termal döngü, 1 döngü $95{ }^{\circ} \mathrm{C}$ 'de $15 \mathrm{dk}, 32 \mathrm{döngü} 95$ ${ }^{\circ} \mathrm{C}^{\prime}$ de $15 \mathrm{sn}$ ve $60{ }^{\circ} \mathrm{C}$ 'de $45 \mathrm{sn}, 1$ döngü $95{ }^{\circ} \mathrm{C}$ 'de $30 \mathrm{sn}, 1$ döngü $50{ }^{\circ} \mathrm{C}$ 'de $30 \mathrm{sn}$ olarak ayarlandı. Multipleks RT-PCR analizi, Rotor-Gene Q (Qiagen, Hilden, Germany) ile gerçekleştirildi. Koşum sonunda endojen kontrol için beklenen en yüksek erime sıcaklığı Tm: $76{ }^{\circ} \mathrm{C}, H L A-B 27$ pozitif erime tepe sıcaklığı Tm: $87,5^{\circ} \mathrm{C}$ idi. Melting curve (erime eğrisi) analizi ile HLA-B27 genotipleri belirlendi. Sadece endojen kontrol pikinin oluştuğu örnekler negatif, hem endojen hem HLA-B27 pikinin oluştuğu örnekler ise pozitif olarak değerlendirildi.

\section{İstatistiksel Analiz}

İstatistiksel analizler SPSS 22.0 (SPSS Inc, Chicago, IL, USA) programı kullanılarak yapıldı. Klinik karşılaştırmalarda normal dağılan sürekli değişkenler t-test ile, kategorik değişkenler ki-kare testi testi ile değerlendirildi. $\mathrm{P}<0.05$ anlamlı kabul edildi.

\section{Bulgular}

Bu çalışmada, 155 AS ön tanılı hastada HLA-B27 sıklığı ve laboratuvar bulgularıyla ilişkisi değerlendirildi. Hastalara ait demografik özellikler ve laboratuvar bulguları Tablo 1.'de verilmiştir. Çalışmaya dahil edilen 155 hastanın 91'i $(\% 58,7)$ kadın, 64'ü $(\% 41,3)$ erkekti ve erkek/kadın oranı 0,7 olarak saptandı. Yaş ortalamaları kadınlarda 40,8 $\pm 11,9$, erkeklerde $41,1 \pm 12,8$ idi. Hastaların CRP seviyeleri ortalaması $12,5 \pm 19,4$, sedimentasyon seviyeleri ortalaması $16,4 \pm 14,4$ olarak bulundu. 31 hastada (\%20) HLA-B27 alel pozitifliği saptandı. 44 hastada $(\% 28,4)$ SpA için aile öyküsü mevcuttu. 
Tablo 1. AS hastalarına ait demografik özellikler ve laboratuvar bulguları

\begin{tabular}{lc}
\hline Özellikler & AS hastaları $(\mathbf{n}=\mathbf{1 5 5})$ \\
\hline Yaş, ortalama \pm SS (yıl) & $40,9 \pm 12,3$ \\
Cinsiyet (Kadın/Erkek) & $91 / 64=1,4$ \\
CRP $(\mathrm{mg} / \mathrm{L})$ & $12,5 \pm 19,4$ \\
Sedimentasyon (mm/h) & $16,4 \pm 14,4$ \\
Aile öyküsü & $\% 28,4$ \\
HLA-B27 sıklığı & $\% 20$ \\
\hline AS, ankilozan spondiliti
\end{tabular}

$H L A-B 27$ alel pozitifliğine göre yapılan karşılaştırmada; HLA-B27 pozitif olanların yaş ortalaması negatif olanlara kıyasla anlamlı olarak daha düşüktü $(p=0,047)$. HLA-B27 pozitifliği erkek cinsiyette kadınlara kıyasla anlamlı olarak daha fazlaydı $(p=0,010)$. Serum CRP ve sedimentasyon seviyeleri $H L A-B 27$ pozitifliğinde belirleyici değildi $(p>0,05)$. HLA-B27 pozitif olan AS hastalarında aile öyküsü olanlar olmayanlara kıyasla daha fazlaydı $(p=0,000)$. HLA-B27 pozitifliğine göre demografik özellikler ve laboratuvar bulguları Tablo 2'de verilmiştir.

Tablo 2. HLA-B27 pozitifliğine göre demografik özellikler ve laboratuvar bulguları

\begin{tabular}{lccc}
\hline Özellikler & HLA-B27+ & HLA-B27- & p değeri $^{*}$ \\
\hline Yaş, ortalama $\pm S S(y ı l)$ & $36,71 \pm 12,4$ & $41,8 \pm 12,1$ & $0,047^{*}$ \\
Cinsiyet (E/K) & $19 / 12$ & $45 / 79$ & $0,010^{*}$ \\
CRP & $17,2 \pm 23,3$ & $11,4 \pm 18,2$ & 0,136 \\
Sedimentasyon & $13,5 \pm 11,3$ & $17,2 \pm 15,1$ & 0,144 \\
Aile öyküsü (Var/Yok) & $21 / 7$ & $22 / 42$ & $0,000^{*}$ \\
\hline CRP, C-reaktif protein; $\pm S S$, standart sapma. ${ }^{*}$ p< 0.05 anlamlı kabul edilmişstir.
\end{tabular}

Cinsiyete göre demografik ve klinik özellikler karşılaştırılığında; hastalık başlangıç yaşında cinsiyet ayrımı yoktu $(p>0,05)$. Serum CRP düzeyleri cinsiyete bağlı fark oluşturmazken, sedimentasyon düzeyleri kadınlarda erkeklere kıyasla anlamlı olarak daha yüksekti $(p=0,000)$. Aile öyküsü pozitifliği cinsiyete göre değişmedi $(p>0,05)$. HLA-B27 pozitifliği erkeklerde kadınlara kıyasla anlamlı şekilde daha fazlaydı $(p=0,014)$. Cinsiyete göre demografik özellikler ve laboratuvar bulguları Tablo 3.'de verilmiştir.

Tablo 3. Cinsiyete göre demografik özellikler ve laboratuvar bulguları

\begin{tabular}{|c|c|c|c|}
\hline Özellikler & Kadın & Erkek & p değeri* \\
\hline Yaş, ortalama \pm SS (y1l) & $40,84 \pm 11,9$ & $40,64 \pm 12,8$ & 0,923 \\
\hline CRP & $11,6 \pm 16,7$ & $13,9 \pm 22,7$ & 0,498 \\
\hline Sedimentasyon & $19,7 \pm 14,4$ & $11,6 \pm 13,1$ & $0,000 *$ \\
\hline Aile öyküsü (Var/Yok) & $21 / 30$ & $23 / 19$ & 0,208 \\
\hline$H L A-B 27(+/-)$ & $12 / 79$ & $19 / 45$ & $0,014^{*}$ \\
\hline
\end{tabular}

CRP, C-reaktif protein; \pm SS, standart sapma. ${ }^{*} \mathrm{p}<0.05$ anlamlı kabul edilmiştir.

\section{Tartışma ve Sonuç}

Ankilozan spondilit, kronik inflamasyon ile karakterize otoimmün bir hastalıktır. Hastalığın etyolojisinde kalıtım, çevre, immünojik faktörler ve mikrobiyom bozuklukları yer almaktadır. Yapılan çalışmalarda AS ile $H L A-B 27$ arasında güçlü bir ilişki gösterilmiştir [4,9]. İkiz çalışmaları, HLA-B27nin bu hastalıktaki toplam genetik riske sadece $\% 20-30$ kadar bir katkısı olduğunu, oysa tüm MHC'lerin yaklaşık \%40-50 
kadar katkıda bulunduğunu göstermektedir [6]. HLA-B27 pozitif monozigotik ikiz çiftleri için uyum oranı $\% 63$, dizigotik ikiz çiftleri için \%23'tür. Ayrıca, birinci derece akrabalarında ankilozan spondilit olan $H L A-B 27$ pozitif bireylerin, aile öyküsü olmayan $H L A-B 27$ pozitif bireylere göre hastalığa yakalanma riski 6 ila 16 kat daha fazladır [10]. AS'de HLA-B27 sıklığı farklı ırk ve etnik gruplarda değişiklik göstermektedir. AS hastalarında HLA-B27 sıklığı Kuzey Avrupa ülkelerinde \%95, Japonya'da \%83, Türkiye'den yapılan birçok çalışmada ise \%70-90 arasında rapor edilmiştir [8]. Çalışmamızda literatürden farklı olarak, 155 AS hastasında HLA-B27 sıklığı \%20 olarak bulunmuştur. Bu farklı sonucun, ön tanılı hastaların çalışmaya dahil edilmesi, çalışma kohortunun farklılığı, klinik varyasyonlar, farklı etnik köken ve farklı genetik ve/veya çevresel faktörlerden kaynaklanmış olabileceğini düşünmekteyiz.

Günal ve ark.'nın yaptıkları çalışmada, AS hasta grubunda erkek/kadın oranını 1,8 olarak raporlamışlardır [8]. Bir başka çalışmada HLA-B27 negatif AS hastalarında erkek/kadın oranı 3 olarak bulunmuştur [11]. AS'li hastalarda yapılan birçok çalışmada hastalık insidansının erkeklerde 2-5 kat daha fazla olduğu gösterilmiştir [12]. Son çalışmalarda erkek/kadın oranının giderek azaldığı görülmektedir. Bizim çalışmamızda da erkek/kadın oranı $(0,7)$ daha düşüktü. Bununla birlikte, $H L A$ B27 pozitifliği erkek cinsiyette kadınlara kıyasla daha fazlaydı.

Feldtkeller ve ark.'nın çalışmasında, AS'in başlangıç yaşının kadınlarda erkeklere göre daha erken olduğu gösterilmiştir [12]. Bu çalışmada ayrıca hastalığın ortalama başlangıç yaşı $25.1 \pm 8.5$ olarak bildirilmiştir [12]. Türk popülasyonunda yapılan çalışmalarda AS hastalığının başlangıç yaşı ortalaması $23,5 \pm 8,9$ olarak raporlanmıştır [8]. Çalışmamızda hastalığın başlangıç yaşı ortalaması literatüren farklı olarak, $40,9 \pm 12,3$ idi. $H L A-B 27$ pozitif olan hastalarda hastalığın başlangıç yaşı anlamlı derecede daha düşüktü (ortalama, $\pm S S, 36,71 \pm 12,4$ ). Kadın ve erkeklerde hastalığın başlama yaşı açısından fark saptanmadı. Wu ve ark.'nın yaptığı çalışmada $H L A-B 27$ ile başlangıç yası arasında ilişki saptanmazken, Khan ve ark. çalışmamızla uyumlu olarak $H L A-B 27$ pozitif hastalarda hastalığın daha erken yaşta başladığını bildirmişlerdir [13,14].

Hastaların laboratuvar parametrelerini incelediğimizde, HLA-B27 negatif ve HLA-B27 pozitif gruplar arasında sedimentasyon ve CRP değerleri benzer olup, fark saptanmamıştır. Daha önce yapılan bazı çalışmalar, HLA-B27 pozitifliğinin daha yüksek sedimentasyon ve CRP gibi inflamatuar belirteçlerle birlikte olabileceğini göstermiştir [15]. Sieper ve ark, sedimentasyon ve CRP düzeylerinin AS hastalarının \%50-70'inde yüksek bulunduğunu bildirmişlerdir [16]. Arévalo ve ark. çalışmamızla uyumlu olarak, sedimentasyon ve CRP değerleri ile $H L A-B 27$ negatif ve $H L A-B 27$ pozitif gruplar arasında fark saptamamışlardır [17].

Literatürde HLA-B27 pozitifliği ile ailede AS öyküsü arasında pozitif korelasyon gösterilmiştir $[8,15,16]$ Günal ve ark, birinci derece akrabalarda AS için aile öyküsünü $\% 12.5$ olarak bildirmişlerdir. Ayrıca aile öyküsünün kadınlarda erkeklere kıyasla anlamlı derecede daha fazla olduğunu raporlamışlardır [8]. İki Avrupa kohortunda yapılan çalışmada, ailede AS öyküsü $H L A-B 27$ ile ilişkilendirilmiştir $[18,19]$. $H L A$ $B 27$ ile aile iliş̧isi derecesinin incelendiği ASAS kohortunda yapılan bir çalışmada, ailede AS öyküsü, hem beyaz hem Asyalı hastalarda, hem birinci hem de ikinci derece akrabalarda $H L A-B 27$ taşıyıcılığı ile güçlü bir şekilde ilişkilendirilmiştir [20]. Çalışmamızda, AS hastalarının \%28,4'ünde aile öyküsü saptandı. HLA-B27 pozitif olanlarda aile öyküsü olanlar aile öyküsü olmayanlara kıyasla daha fazlaydı. Kadın ve erkeklerde aile öyküsü açısından fark saptanmadı. HLA-B27 pozitif bireylerde aile öyküsü daha sık görülmekle beraber, kohortumuzda juvenil başlangıçlı AS hastasının olmamasından dolayı tanının erken konulmasına yardımcı olduğu söylenemez. AS'de aile öyküsünün önemi, hastalığın patogenezindeki genetik etkenlerin katkısı göz önüne alındığında beklenen bir durum olarak değerlendirilmiştir.

Çalışmamızın bazı sınırlılıkları bulunmaktadır. Bunların başında örneklem sayısının nispi düşüklüğü gelmektedir. Ayrıca AS ön tanılı hastaların çalışmaya dahil edilmesi hastalığın frekansını düşük saptamamıza neden olmuştur. Çalışma kohortumuza kontrol grubunun dahil edilememesi de diğer bir sınırılıktır. Bununla birlikte, hastalığın patofizyolojisinde rol alan genetik değişimleri ortaya koymak için tek başına $H L A-B 27$ alelinin değerlendirilmesi yeterli değildir.

Sonuç olarak, AS semptom ve bulgularını taşıyan hastalarda, HLA-B27 pozitiflik oranı daha önce Türkiye'de bildirilen oranlara kıyasla daha düşük bulundu. Çalışmamızda $H L A-B 27$ pozitiflik oranı düşük olsa da, çalışmaya AS semptomlarını taşıyan hastaların dahil edildiği düşünüldüğünde, spondiloartropati endikasyonlu hastalarda genetik testin önemi ortaya koyulmuştur. Toplumumuzda 
HLA-B27'nin AS hastalarındaki sıklığını ve hastalığın patogenezindeki rolünü daha net ortaya koyabilmek için, tüm alt tipleri ile birlikte daha geniş hasta popülasyonlarında çalışılmasını önermekteyiz.

\section{Kaynakça}

[1] Brown MA. Progress in the genetics of ankylosing spondylitis. Brief Funct Genomics 2011;10(5):249-57.

[2] Dakwar E, Reddy J, Vale FL, Uribe JS. A review of the pathogenesis of ankylosing spondylitis. Neurosurg Focus 2008;24(1):E2.

[3] Dean LE, Jones GT, Macdonald AG, Downham C, Sturrock RD, Macfarlane GJ. Global prevalence of ankylosing spondylitis. Rheumatol (United Kingdom) 2014;53(4):650-7.

[4] Diyarbakır E. The Distribution of HLA B27 in Patients with Ankylosing Spondylitis in Eastern Anatolia. J Inonu Univ Med Fac 2012;19(1):23-5.

[5] Chen B, Li J, He C, Li D, Tong W, Zou Y, et al. Role of HLA-B27 in the pathogenesis of ankylosing spondylitis (Review). Mol Med Rep 2017;15(4):1943-51.

[6] Pekacar FS, Akdoğan A, Hayran M, Çolak R, Yılmaz E. Ankilozan spondilit ile HLA-B27, MEFV gen mutasyonları, ERAP1, IL12B ve IL23R gen polimorfizmleri arasındaki ilişki. Turkish J Biochem $2014 ; 39(4): 482-7$.

[7] Yang T, Duan Z, Wu S, Liu S, Zeng Z, Li G, et al. Association of HLA-B27 genetic polymorphisms with ankylosing spondylitis susceptibility worldwide: A meta-analysis. Mod Rheumatol 2014;24(1):150-61.

[8] Gunal EK, Sarvan FO, Kamali S, Gul A, Inanc M, Carin M, et al. Low frequency of HLA-B27 in ankylosing spondylitis patients from Turkey. Jt Bone Spine 2008;75(3):299-302.

[9] Pedersen SJ, Maksymowych WP. The Pathogenesis of Ankylosing Spondylitis: an Update . Curr Rheumatol Rep 2019;21(10):58.

[10] Brown MA, Kennedy LG, MacGregor AJ, Darke C, Duncan E, Shatford JL, et al. Susceptibility to ankylosing spondylitis in twins: The role of genes, HLA, and the environment. Arthritis Rheum 1997;40(10):1823-8.

[11] Cipriani A, Rivera S, Hassanhi M, Márquez G, Hernández R, Villalobos C, et al. HLA-B27 subtypes determination in patients with ankylosing spondylitis from Zulia, Venezuela. Hum Immunol 2003;64(7):745-9.

[12] Feldtkeller E, Khan MA, Van Der Heijde D, Van Der Linden S, Braun J. Age at disease onset and diagnosis delay in HLA-B27 negative vs. positive patients with ankylosing spondylitis. Rheumatol Int 2003;23(2):616.

[13] Wu Z, Lin Z, Wei Q, Gu J. Clinical features of ankylosing spondylitis may correlate with HLA-B27 polymorphism. Rheumatol Int 2009;29(4):389-92.

[14] Khan MA, Kushner I, Braun WE. Comparison of clinical features in HLA-B27 positive and negative patients with ankylosing spondylitis. Arthritis Rheum 1977;20(4):909-12.

15] Mekhola MH, Chowdhury MAJ, Ahmed MS, Khan AH, Paul S. Frequency of HLA-B27 gene among patients with ankylosing spondylitis and its consequences on clinical manifestation. BIRDEM Med J 2019;9(3):18892.

[16] Sieper J, Braun J, Rudwaleit M, Boonen A, Zink A. Ankylosing spondylitis: An overview. Ann Rheum Dis 2002;61 Suppl 3(Suppl 3):iii8-18.

[17] Arévalo M, Gratacós Masmitjà J, Moreno M, Calvet J, Orellana C, Ruiz D, et al. Influence of HLA-B27 on the Ankylosing Spondylitis phenotype: Results from the REGISPONSER database. Arthritis Res Ther 2018;20(1).

[18] Akkoç N, Yarkan H, Kenar G, Khan MA. Ankylosing Spondylitis: HLA-B²7-Positive Versus HLA-B²7Negative Disease. Curr Rheumatol Rep 2017 May;19(5):26.

[19] Ez-Zaitouni Z, Hilkens A, Gossec L, Berg IJ, Landewé R, Ramonda R, et al. Is the current ASAS expert definition of a positive family history useful in identifying axial spondyloarthritis? Results from the SPACE 
and DESIR cohorts. Arthritis Res Ther 2017;19(1).

[20] van Lunteren M, Sepriano A, Landewé R, Sieper J, Rudwaleit M, van der Heijde D, et al. Do ethnicity, degree of family relationship, and the spondyloarthritis subtype in affected relatives influence the association between a positive family history for spondyloarthritis and HLA-B27 carriership? Results from the worldwide ASAS cohort. Arthritis Res Ther 2018;20(1). 